\title{
Mercury uptake and phytotoxicity in terrestrial plants grown naturally in the Gumuskoy (Kutahya) mining area, Turkey
}

\author{
Merve SASMAZ $^{1}$, Bunyamin Akgül ${ }^{2}$, Derya Yıldırım ${ }^{2}$, Ahmet SASMAZ ${ }^{2} *$
}

\begin{abstract}
This study investigated Hg uptake and transport from the soil to different plant parts by documenting the distribution and accumulation of $\mathrm{Hg}$ in the roots and shoots of 8 terrestrial plant species, all of which grew naturally in surface soils of the Gumuskoy Pb-Ag mining area, with continental climate.
\end{abstract}

Key Words: Mercury uptake, wild plants, enrichment coefficient, translocation factor, phytoremediation, mining area

\section{Introduction}

Mercury is one of the most toxic heavy metals and is considered as a global contaminant. Its toxic level varies as a function of the exposure pathway and the chemical species in which mercury occurs [1],[2],[3]. It is also very expensive to clean up, because of its accumulative and persistent character in the biota [4]. As a highly bio-accumulated toxic metal in the food chain, mercury $(\mathrm{Hg})$ possesses increasingly environmental concerns worldwide. There are many large $\mathrm{Hg}$ mines abandoned recently because of lower $\mathrm{Hg}$ prices and low demands. The presence of those abandoned $\mathrm{Hg}$ mines continues to impact the local environments through minewastes, drainage and elemental mercury vapor. Because the ecological and toxicological effects of $\mathrm{Hg}$ are strongly dependent on the chemical species present, the primary concern about those $\mathrm{Hg}$ mines is the biological accumulation [5]. Direct $\mathrm{Hg}$ contamination is usually the result of releases from abandoned $\mathrm{Hg}$ mines, gold-silver-thallium and other mining activities or the chlorine-alkali industry, while indirect (non-point source) contamination is largely attributed to atmospheric deposition originating from coal-fired power plants [5],[6],[7],[8]. It has been estimated that it would cost 40,000 to 70,000 US\$ to remove each pound of $\mathrm{Hg}$ from the environment with currently available technologies; thus, there is an urgent need for the development of alternative $\mathrm{Hg}$ remediation strategies. The potential application of phytoremediation to $\mathrm{Hg}$ contamination has been explored in several environmental settings. There is evidence that certain plant species have the ability to extract and accumulate $\mathrm{Hg}$ both from atmospheric and soil sources, although no species with Hg hyperaccumulating properties has been identified [9]. The accumulation of mercury in terrestrial plants has been reported to be related to soil characteristics, including concentration of the element [10], but also the uptake of $\mathrm{Hg}$ has been found to be plant-specific [11], [12]. Soil

${ }^{1}$ Department of Environmental Engineering, Firat University, Elazig, Turkey ${ }^{*}$ Department of Geological Engineering, Firat University, Elazig, Turkey characteristics such as high $\mathrm{pH}$ value, abundant lime and accumulated salt reduce its uptake by plants. A highly significant correlation exists between mercury and organic matter content in the top layer of forest soils [13]. In Turkey, many researchers have studied the distribution and speciation of $\mathrm{Hg}$ and heavy metals in foods, drinking and river waters, agricultural soils, and environmental samples [14], [15], [16].

The aim of the present study was to investigate $\mathrm{Hg}$ uptake and transport from soil to plant parts by studying distribution and accumulation of $\mathrm{Hg}$ in the roots and shoots of 8 wild plant species growing naturally in $\mathrm{Hg}$-contaminated surface soils of the Gumuskoy Ag-Tl-As mining area in order to assess its $\mathrm{Hg}$ pollution degree and to contribute to the knowledge about the $\mathrm{Hg}$ soil/plant relationship.

\section{Material and Method}

\section{A. The study area}

In the present study, the plants and the associated soil samples were collected from an area by polymetallic ore deposits in the Gumuskoy mining district, Kutahya, Western Turkey. In this region, outcrops comprise of metamorphic, volcanic, and sedimentary rocks ranging from Permian to present-day. A number of polymetallic ore deposits represented by $\mathrm{Ag}, \mathrm{As}, \mathrm{Tl}, \mathrm{Pb}, \mathrm{Zn}$ and $\mathrm{Sb}$ occur between the Gümüşköy and Şahin villages. Soil and plants in the study area are naturally polluted by these heavy metals. This region has at least $3534 \pm 24$ years of mining history, according to ${ }^{14} \mathrm{C}$ absolute age determinations on charcoal discovered in mining waste by [17]. Consequently, the area has been heavily charged with different metals arising from both ancient and modern mining activities [18],[19],[20]. Intensive mining operations continue in this region in the present day.

\section{B. Plant and soil samples}

The plant samples, consisting of their roots-shoots together with their associated soils, were taken from forty-one sites in the study area. The plant species in the Gumuskoy region can grow under severe climate conditions due to their massive and deep-reaching root systems. These systems also give them the ability to live in areas deficient in organic matter. The $\mathrm{Hg}$ content was measured in 8 plant species that grow in the area: Alyssum saxatile L. (AL), Anchusa arvensis L. (AN), Centaurea cyanus L. (CE), Glaucium flavum (GL), Onosma sp. (ON), Phlomis sp. (PH), Silene compacta (SL) and Verbascum thapsus L. (VR). These plants were chosen because they are native and dominant species in the study area. 


\section{Preparation of Samples}

Soil Samples: Soil thicknesses in the study area vary between $30-40 \mathrm{~cm}$. and $5-6 \mathrm{~m}$. The soils are generally lightdark brown and black color, with a loamy and peaty clay texture (23.6\% sand, $51.4 \%$ silt and $19.3 \%$ clay), with $\mathrm{pH}$ between 6.4 and 7.2, and with an organic matter content of 2.32-6.48 \%. An X-ray diffraction study on the clay minerals was not performed. Soil samples were collected from around the roots of the plants at a depth of 30-40 cm. After drying in an oven at $100{ }^{\circ} \mathrm{C}$ for $4 \mathrm{~h}$ and removing rocks, the soil samples were ground using hand mortars. Soil samples were digested in a mixture of $\mathrm{HCl}: \mathrm{HNO}_{3}: \mathrm{H}_{2} \mathrm{O}(1: 1: 1, \mathrm{v} / \mathrm{v} ; 6 \mathrm{ml}$ per $1.0 \mathrm{~g}$ of soil) for one hour at $95{ }^{\circ} \mathrm{C}$. This treatment dissolved all soil samples except for silicates, and the digests were analyzed using ICP/AES \& MS techniques for $\mathrm{Hg}$ at the ACME Analytical Labs, Vancouver, Canada (www.acmelab.com).

Plant samples: Plant samples were randomly collected from sites that were chosen based on representative characteristics of the Gumuskoy mining area. Three samples of shoots and roots were taken from each sampling site. The root samples were taken at a depth of 30-40 $\mathrm{cm}$ below the surface. The shoot and root samples of the studied plants were thoroughly washed with tap water, rinsed with distilled water, and dried at $100{ }^{\circ} \mathrm{C}$ in an oven for thirty minutes and then at $60{ }^{\circ} \mathrm{C}$ for 24 hours. A chelating EDTA wash was applied, and no differences were observed between EDTA washing and without EDTA washing. The dried plant samples (approximately 2.0-3.0 g) were ashed by heating at $300{ }^{\circ} \mathrm{C}$ for 24 hours. The ashed samples were digested in $\mathrm{HNO}_{3}$ (Merck, Darmstadt, Germany) for one hour, followed by digestion in a mixture of $\mathrm{HCl}: \mathrm{HNO}_{3}: \mathrm{H}_{2} \mathrm{O}(1: 1: 1$, v/v; $6 \mathrm{ml}$ per $1.0 \mathrm{~g}$ of the ashed sample) for one hour at $95{ }^{\circ} \mathrm{C}$. The digests were analyzed using ICP/AES \& MS techniques for $\mathrm{Hg}$ and the plant concentrations were calculated on a dry matter basis.

\section{Enrichment coefficients of roots (ECR)}

Enrichment coefficients were found by calculating the ratios of specific activities in plant roots and soils (concentration in ppb of plant root divided by concentration in ppb of soil). This value is used as an index to determine accumulation of trace elements in plant parts or to establish the transfer of elements from soil to plant root [21].

\section{E. Enrichment coefficient for shoots (ECS)}

Enrichment coefficients were also calculated for shoots (ECS) (concentration in ppb of plant shoot divided by concentration in $\mathrm{ppb}$ of soil). The ECS is a very important factor, as it indicates the capacity of a given species for phytoremediation [22] and this value is also used as an index to characterize the transfer of elements from the soil to the plant shoot. The ECS therefore characterizes the capability of a plant to absorb and transport metals from sediment and then to store them in the above-ground parts [23], [24], [25].

\section{F. Translocation factors (TLF)}

Translocation factors (TLF) are obtained by calculating the ratio of metal in plant shoot to that in the plant roots (concentration in ppb of plant shoot divided by concentration in ppb of root). In a metal accumulator species, a translocation factor greater than 1 is common, whereas in metal excluder species, translocation factors are typically lower than 1 [26].

\section{Results and Discussion}

\section{A. Hg concentrations in soil}

The soil samples were collected from Aktepe and Gözeçukuru area in the study area and its surroundings. $\mathrm{Hg}$ contents of the soil samples were found out to be between 79 and $62532 \mathrm{ppb}$ (mean: $7057 \mathrm{ppb}$ ). $\mathrm{Hg}$ concentrations in similar mining areas range from 8.4 to $610 \mathrm{ppm}$ in Lanmuchang, Guizhou (southwestern China) $\mathrm{Hg}-\mathrm{Tl}$ ore deposits [16]; 5 to $1710 \mathrm{ppm}$ in Almadén mine (Spain) [27]; 12.1 to $100 \mathrm{ppm}$ in Türkönü mercury mine, Turkey [28]; 0.21 to $3.4 \mathrm{ppm}$ in ancient mining area of England [29] and 0.2 to $1.9 \mathrm{ppm}$ in $\mathrm{Hg}$ mining of Canada; 2.6 to $2.9 \mathrm{ppm}$ in $\mathrm{Hg}$ mining of France; 0.09 to $0.22 \mathrm{ppm}$ in $\mathrm{Hg}$ mining of Brazil [30]. This mean value of $\mathrm{Hg}$ in the study area is lower than from mercury contents in the soils around these mercury deposits but many times higher than average mercury contents of lithosphere $(0.05 \mathrm{ppm})$ and unpolluted soils $(0.03 \mathrm{ppm})$ [31]. Mercury out of mining are also observed in soils around coal power stations and metallurgic plants (0.4-7.55 ppm), in some chemical works [32] and at former battery recycling facility [33]. This higher $\mathrm{Hg}$ concentration can be related to the $\mathrm{Ag}$, $\mathrm{Tl}$, As, and $\mathrm{Pb}$ deposits of the Gumuskoy region, because the presence of $\mathrm{Hg}$ showed a linear correlation with the occurrence of some heavy metals These linear correlations ( $r=$ 0.48-0.54) were observed between $\mathrm{Hg}$ and the heavy metals $\mathrm{Pb}, \mathrm{As}, \mathrm{U}, \mathrm{Sb}, \mathrm{Tl}$ and $\mathrm{Ba}$, whereas weak linear correlations $(\mathrm{r}=$ 0.04-0.10) were observed between $\mathrm{Hg}$ and the heavy metals $\mathrm{Sr}, \mathrm{Cd}, \mathrm{Ca}$ and $\mathrm{P}$ (Table 1). The linear correlations between $\mathrm{Hg}$ and heavy metals $(\mathrm{Pb}, \mathrm{As}, \mathrm{U}, \mathrm{Sb}, \mathrm{Tl}$ and $\mathrm{Ba}$ ) supported the idea that $\mathrm{Hg}$ and heavy metals were geologically transported jointly to the soil of the study area in hydrothermal solutions.

Significant relationships were detected between $\mathrm{Hg}$ content in all plant samples and in soils in this study. $\mathrm{Hg}$ in roots changes as a $2^{\text {nd }}$ degree polynomial regarding in soil. This means that the more $\mathrm{Hg}$ in soil the more $\mathrm{Hg}$ in root is accumulated. From the Fig. 1, it is also seen clearly $\mathrm{Hg}$ content in shoot increases exponentially with a decreasing slope. This indicates that roots function as a barrier for $\mathrm{Hg}$ to move upright to the shoots by accumulating more $\mathrm{Hg}$ with the increasing to $\mathrm{Hg}$ content in soil. The mechanisms for absorption and transport of $\mathrm{Hg}$ differed among plants in the study area. These variations in $\mathrm{Hg}$ content in different plants and plant tissues might be genetically controlled by the genotype of plants [34].

The highest $\mathrm{Hg}$ concentration in all analyzed soils was 62532 and $49871 \mathrm{ppb}$ in the GL-01 and GL-02 samples (Fig. 1 ), which were collected from a mineralized area. These soils also had high $\mathrm{As}, \mathrm{Sb}, \mathrm{Tl}, \mathrm{Pb}$ and $\mathrm{Ba}$ concentrations. $\mathrm{Hg}$ mobility in different surface conditions is believed to be medium in oxidizing conditions but high in acid and humid environments [35]. In the soils of the Gumuskoy study area, the maximum concentration of $\mathrm{Hg}$ was vertically accumulated 
at the surface or bulk close to surface. The soils with maximum $\mathrm{Hg}$ concentration like other heavy metals $(\mathrm{Pb}, \mathrm{Ag}$, $\mathrm{Zn}, \mathrm{Se}, \mathrm{Sb}, \mathrm{Tl})$ were generally in brown and dark color and contained more clay and organic matter. The $\mathrm{Hg}$ content decreased sharply with increasing depth of soil profile, where the soils were generally light brown color and contained more sand and rock parts and less organic matter.

\section{B. Hg concentrations in plants}

In the Gumuskoy mining area, 8 plant species were selected for determination of $\mathrm{Hg}$ contents. The chosen plants grow indigenously in the mining area and generally live for one year or two years (annual). The $\mathrm{Hg}$ contents of plants in the study area varied considerably, but the average $\mathrm{Hg}$ concentrations for plant roots and shoot were 571 and 233 $\mathrm{ppb}$, respectively. However, $\mathrm{Hg}$ concentrations of forty-one plant samples ranged from a minimum of 2 and $1 \mathrm{ppb}$ for both plant roots and shoots to a maximum of 7328 and $1299 \mathrm{ppb}$ for plant roots and shoots, respectively. Mercury concentrations (ppb dry weight) of plant parts are given in Fig. 1, together with $\mathrm{Hg}$ concentrations of the associated soils.

The mean $\mathrm{Hg}$ values in the soil, roots, and shoots of Alyssum saxatile (AL), were 5243, 746, and $155 \mathrm{ppb}$, respectively. The $\mathrm{Hg}$ levels in the soil around AL plants were significantly higher than the mean $\mathrm{Hg}$ values in AL shoots and roots. The $\mathrm{Hg}$ levels for all $\mathrm{AL}$ samples ranged between 45 and $2813 \mathrm{ppb}$ for roots, and between 26 and $300 \mathrm{ppb}$ for shoots on a dry weight basis (Fig. 1). The Hg enrichment coefficients (ECR and ECS) for AL roots and shoots are shown in Fig. 2; the mean ECR and ECS values were 0.10 and 0.04, respectively. Translocation factors (TLFs) for $\mathrm{Hg}$ in $\mathrm{AL}$ were between 0.06 and 2.26 (mean: 0.85) in this study (Fig. 2), which indicates that $\mathrm{Hg}$ was only weakly transferred to the shoot following uptake from the soil to root.

$\mathrm{Hg}$ concentrations in the soil, roots, and shoots of Anchusa arvensis (AN) are given in Fig. 1. Mean $\mathrm{Hg}$ values in the soil, roots, and shoots for AN were similar, at 6959, 485, and 500 ppb, respectively, on a dry weight basis (Fig. 1). The enrichment coefficients (ECR and ECS) for Se in the roots and shoots of AN, shown in Fig. 1.The mean values of 0.06 and 0.06 , respectively, indicated that $\mathrm{Hg}$ taken up from the soil by AN was transferred to the root. The translocation factor (TLFs) of AN was 1.03 for two samples (Fig. 1); which meant that $\mathrm{AN}$ translocation factor was bigger than 1. This result indicates that $\mathrm{AN}$ has very well transporting capacity for $\mathrm{Hg}$ in semi-arid environments or continental climates.

The mean Se concentrations in the soil, roots, and shoots of Centaurea cyanus (CE) were 2052, 90 and $187 \mathrm{ppb}$, respectively (Fig. 1). The mean $\mathrm{Hg}$ values in the shoots of two $\mathrm{CE}$ samples were higher than the mean $\mathrm{Hg}$ values in the roots, but equal in one sample. However, the mean ECR and ECS of all samples were very low but the TLFs of CE samples were higher than 1 for two samples, equal for one sample (Fig. 2). This value indicates that $\mathrm{CE}$ is not very good bioaccumulator plant for $\mathrm{Hg}$ when growing in a similar environment and climate.
The mean $\mathrm{Hg}$ concentrations in the soil, roots, and shoots of Glaucium flavum (GL) were 56202, 5245 and 950 ppb, respectively. The ECR, ECS, and TLF values for GL (mean $=0,09,0,02$ and 0,25 respectively) were lower than 1 (Fig. 2).

The mean $\mathrm{Hg}$ concentrations in the soil, roots, and shoots of Onosma (ON) were 6455, 87 and $171 \mathrm{ppb}$, respectively (Fig. 1). The $\mathrm{Hg}$ values in the shoots of all ON samples were higher than the $\mathrm{Hg}$ values in the roots, but lower than the $\mathrm{Hg}$ values in the soils. Therefore, the ECR and ECS values for ON are lower than 1, but the TLF values are higher than 1 . These values indicate that the ON root does not accumulate $\mathrm{Hg}$ from the soil, but it efficiently transfers $\mathrm{Hg}$ to the shoot.

The Hg contents of the soil, roots, and shoots of Phlomis (PH) were examined in four samples. The mean $\mathrm{Hg}$ concentration of the soil, roots, and shoots of PH were 1960, 160 and $369 \mathrm{ppb}$, respectively. The $\mathrm{Hg}$ concentrations in shoots of two $\mathrm{PH}$ samples were higher than the $\mathrm{Hg}$ concentrations in the soil but other two samples were lower than the $\mathrm{Hg}$ concentrations in their soils. The mean ECR, ECS, and TLF values for PH were $0.21,0.56$ and 2.05, respectively. The ECS and TLF of PH-03 and PH-04 samples were than higher than 1 (ECS: 1.03 and TLF: 3.39 for PH-03 sample; ECS: 1.02 and TLF: 2.40 for PH-04 sample). These values indicate that $\mathrm{PH}$ would be effective at cleaning or rehabilitating the soils in areas contaminated by $\mathrm{Hg}$.

The mean $\mathrm{Hg}$ concentrations in the soil, roots, and shoots of Silene compacta (SL) were 448, 8 and $14 \mathrm{ppb}$, respectively (Fig. 1). The $\mathrm{Hg}$ values in the soil were higher than in SL roots and shoots. The mean ECR and ECS values for this plant were lower than 1 . The TLFs of SL were generally higher than 1 (mean 1.66), except for one sample. This means that $\mathrm{Hg}$ was not transferred from the soil to the root or the shoot by this plant (Fig. 2). This indicates that SL cannot act as a $\mathrm{Hg}$ bioaccumulator plant.

The $\mathrm{Hg}$ contents of the soil, roots, and shoots were analyzed in five samples of Verbascum thapsus (VR). The mean $\mathrm{Hg}$ concentrations in the soil, roots, and shoots of VR were 4625, 145, and $139 \mathrm{ppb}$, respectively. The $\mathrm{Hg}$ concentrations in VR shoots and roots were lower than the $\mathrm{Hg}$ concentrations in soil but the $\mathrm{Hg}$ concentrations in shoots of VR were higher than the $\mathrm{Hg}$ concentrations in roots of VR, except for one sample (Fig. 1). The mean ECR, ECS and TLF values for VR were $0.03,0.06$, and 2.47 , respectively. The TLF values (2.47) were higher than 1 and this value indicates that VR has ability to transport from roots to shoots for $\mathrm{Hg}$.

\section{Conclusions}

The Hg levels of soils from the Gumuskoy Ag-As mining area varied between 79 and 62532 ppb (mean: $7057 \mathrm{ppb}$ ), which are somewhat higher than those of uncontaminated surface soils reported in other countries. The distribution and accumulation of $\mathrm{Hg}$ was examined in roots and shoots of 8 different plant species growing naturally in the Gumuskoy soils. The mean concentrations of $\mathrm{Hg}$ in roots and shoots of these plants were found $571 \mathrm{ppb}$ and $233 \mathrm{ppb}$, respectively. These results show that the fraction of available $\mathrm{Hg}$ for plants in soils of Gumuskoy mining zones was lower than in their 
soils and but higher than $\mathrm{Hg}$ concentrations of plants grown in uncontaminated areas, despite toxic levels of $\mathrm{Hg}$ are found in these soils. Hg concentrations in studied plants grown on these soils can be considered as phytotoxic, although no symptoms of $\mathrm{Hg}$ toxicity are observed in any of the studied plant species. The main reason for this, the roots of studied plants functioned like a barrier in root preventing that $\mathrm{Hg}$ from reaching the aerial parts of plants. However, according to TLF values, $A$. arvensis (AN), C. cyanus (CE), Onosma sp. (ON), Phlomis sp. (PH), S. compacta (SL), and V. thapsus L. (VR) showed a higher ability in increasing to $\mathrm{Hg}$ transport from roots to shoots. These results can make them good candidates for $\mathrm{Hg}$ phytoremediation of contaminated soils. A. saxatile L. (AL), and G. flavum (GL), had a lower ability to reduce $\mathrm{Hg}$ transport to shoots from roots because these plants behaved as excluders for $\mathrm{Hg}$, storing the metal mainly in the root.

\section{Acknowledgment}

This work is part of a research project supported by TUBITAK (CAYDAG 110 Y 003).

\section{References}

[1] A. Ferrer. Intoxicación por metals. Anales Sis San 26 (2003), 141-153.

[2] L. Rodriguez, F. Lopez-Bellido, A. Carnicer, V. Alcalde. Phytoremediation of mercury-polluted soils using crop plants. Fresen. Environ. Bull. 12 (2003), 967-971

[3] M.J. Sierra, R. Millan, E. Esteban. Mercury uptake and distribution in Lavandula stoechas plants grown in soil from Almadén mining district (Spain).Food and Chemical Toxicology 47 (2009),pp. 2761-2767.

[4] A. Pérez-Sanz, R. Millán, M.J. Sierra, R. Alarcón, P. García, M. Gil-Díaz, S. Vazquez, M.C. Lobo, Mercury uptake by Silene vulgaris grown on contaminated spiked soils. J. Environ Man., 95 (2012), 233-237.

[5] G.L. Qiu, X.B. Feng, S.F. Wang, T.F. Xiao. Mercury contaminations from historic mining to water, soil and vegetation in Lanmuchang, Guizhou, southwestern China Sci Total Environment 368 (2006); 56-68.

[6] S.M. Ullrich, T.W. Tanton, S.A. Abdrashitova. Mercury in aquatic environment: a review of factors affecting methylation. Crit. Rev. Environ. Sci Technol. 31 (2001), 241-243.

[7] T.F.Xiao, J.Guha, D.Boyle, C.Q.Liu, J.A.Chen. Environmental concerns related to high thallium levels in soils and thallium uptake by plants in southwest Guizhou China. Sci Total Environ 318 (2004), pp. 223 -44.

[8] S. Chattopadhyay, R.L. Fimmen, B.J. Yates, V. Lal, P. Randall. Phytoremediation of mercury and methyl mercury-contaminated sediments by water hyacinth. Int. J. Phytorem (2012), 142-161.

[9] C.L. Rugh, S.P. Bizily, R.B. Meagher. Phytoremediation of Environmental Hg Pollution In: Phytoremediation of Toxic Metals: Using Plants to Clean Up the Environment. Hoboken, NJ (1999) 151-170.

[10] D.C. Adriano. Trace Elements in the Terrestrial Environment: Biogeochemistry, Bioavailability and Risk of Metals. Springer, (2001).

[11] M. Patra, A. Sharma. Mercury toxicity in plants. Botanical Review 66 (2000), 379-422.

[12] J.A. Molina, R. Oyarzun, J.M. Esbri, P. Higuera. Mercury accumulation in soils and plants in the Almaden mining district, Spain: one of the most contaminated sites on Earth Environ Geochem Health 28(2006), 487-498

[13] J. Lag, E. Steinnes. Regional distribution of mercury in humus layers of Norwegian forest soils. Acta Agric. Scand. 28 (1978), 393-396.

[14] M. Tuzen, M. Soylak. Mercury Contamination in Mushroom Samples from Tokat-Turkey. Bull. Environ Contam \& Toxic 74 (2005), 968-972.

[15] M. Tuzen, I. Karaman, D. Citak, M. Soylak. Mercury (II) and Methyl Mercury Determinations in Water and Fish Samples by Using Solid Phase Extraction and Cold Vapour Atomic Absorption Spectrometry Combination. Food and Chemical Toxicology 47 (2009), 1648-1652.

[16] M. Tuzen, I. Karaman, D. Citak, M. Soylak. Mercury (II) and Methyl Mercury Speciation on Streptococcus Pyogenes Loaded Dowex Optipore SD-2. Journal of Hazardous Materials 169 (2009), 345-350.
[17] A. Kartalkanat. Anadolu'da madenciliginin tarihçesi; KütahyaGümüsköy'de 3500 Yıldır süren madencilik çalışmaları. MTA Dergisi 137 (2008), 91-97.

[18] F. Arik. Gümüşköy (Kütahya, Turkey) gümüş yataginin jeokimyasal modellemesi. Selçuk Üniv. Fen. Bilim. Enst. PhD Thesis, (2002), 318 p.

[19] F. Arik, M.T. Nalbantcilar. Maden Isletmeciliginin Çevre ve Halk Sagligina Etkisi, Gümüsköy-Kütahya, 1.Tıbbi Jeoloji Sempozyumu, MTA Gen. Müd. Kültür Sitesi, Ankara, Bildiri Özleri, (2005), 63-64.

[20] F. Arik, T. Yaldız. Heavy Metal Determination and Pollution of the Soil and Plants of Southeast Tavşanlı. Soil, Air, Water 38 (2010), 1017-1030.

[21] S.B. Chen, Y.G. Zhu, Q.H. Hu. Soil to plant transfer of ${ }^{238} \mathrm{U}$, ${ }^{226} \mathrm{Ra}$ and ${ }^{232} \mathrm{Th}$ on $\mathrm{U}$ mining-impacted soil from southeastern China J. Environ.Radioac. 82(2005), 223-236

[22] F.J. Zhao, E. Lombi, S.P. Mc Grath.Assessing the potential for zinc and cadmium phytoremediation with the hyperaccumulator Thlaspi caerulescens. Plant \& Soil 249 (2003), 37-43.

[23] A.J.M. Baker, R.D. Reeves, A.S.M. Hajar. Heavy metal accumulation and tolerance in British populations of the metallophyte Thlaspi caerulescen. New Phytologist 127 (1994), 61-68.

[24] S.L. Brown, R.L. Chaney, J.S. Angle, A.J.M. Baker. Phytoremediation potential of Thlaspi caerulescens and bladder campion for zinc-and cadmium-contaminated soil. J. Environ. Qual. 23 (1994), 1151-1157.

[25] C.Y. Wei, T.B. Chen, Z.C. Huang. Cretan bake (Pteris cretica L.): an arsenic-accumulating plant. Acta Ecol. Sinica 22 (2002), 777-782.

[26] Y.Q. Zu, Y. Li, J.J. Chen, H.Y. Chen, L. Qin, C. Schvartz. Hyperaccumulation of $\mathrm{Pb}, \mathrm{Zn}$ and $\mathrm{Cd}$ in herbaceous grown on lead-zinc mining area in Yunnan China. Environ. Int. 31 (2005), 755-762.

[27] R. Millán, R. Gamarra, T.Schmid, M.J. Sierra, A. Quejido, D.M. Sánchez, A.I. Cardona, M. Fernández, R. Vera. Mercury content in vegetation and soils of the Almaden mining area. Sci. Total Environ 368 (2006), 79-87

[28] U. Gemici, G. Tarcan. Assessment of the pollutants in farming soils and waters around untreated abandoned Türkonü Mercury Mine (Turkey). Bull Environ Contam Toxicol 79 (2007), 20-24.

[29] Davies, B.E. Mercury content of soil in W.Braitain with special reference to contamination from base metal mining. Geoderma 16 (1976), 183

[30] A. Kabata-Pendias, H. Pendias. Trace elements in soils and plants. CRC Press: Washington, D.C. (2001).

[31] I. Pais, J.B. Jones. The handbook of trace elements. St. Lucie Press. 2000

[32] E.A. Henry, L. Hansen, V. Kuhnel, A. Bland. Determination of soil mercury cleanup based on volatilization measurements. Proc. $5^{\text {th }}$.Inter. Conf. Mercury as a global Pollutant, Rio de Janeiro, (1999), p. 572.

[33] J. Lis, A. Pasieczna. Geochemical Atlas of Poland, PIG, Warsaw (1995).

[34] C.X. Li, H. Cao. The research overview of the nutrition characteristics, absorption and transformation of the plant selenium. J. Agricul. Sci. 27 (4) (2006), pp. 72-76.

[35] J. Plant, D. Smith, B. Smith, L. Williams. Environmental geochemistry at the global scale. Applied Geochemistry 16 (11-12) (2001), 1291-1308.

About Authors:

\begin{tabular}{|l|l|}
\hline & $\begin{array}{l}\text { Merve SASMAZ } \\
\text { PhD student in the Department of } \\
\text { Environmental Engineering, Firat } \\
\text { University, Elazig Turkey. } \\
\text { Research interests: Aquatic plants, } \\
\text { Accumulation, Phytoremediation, } \\
\text { Rehabilition of polluted areas }\end{array}$ \\
\hline
\end{tabular}

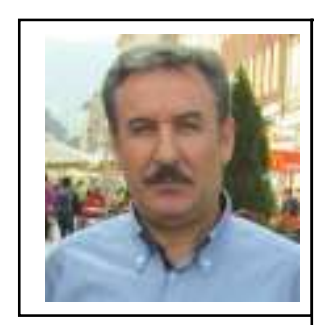

Dr. Bunyamin Akgul

Ass. Prof, Department of Geological

Engineering, Firat University, Elazig

Turkey

Specialist in rock and mineral

geochemistry

Research interests: Petrology,

granitoids, volcanic rocks 
Proc. of the Intl. Conf. on Advances in Applied science and Environmental Technology - ASET 2015.

Copyright $(\odot$ Institute of Research Engineers and Doctors, USA .All rights reserved.

ISBN: 978-1-63248-040-8 doi: 10.15224/ 978-1-63248-040-8-42
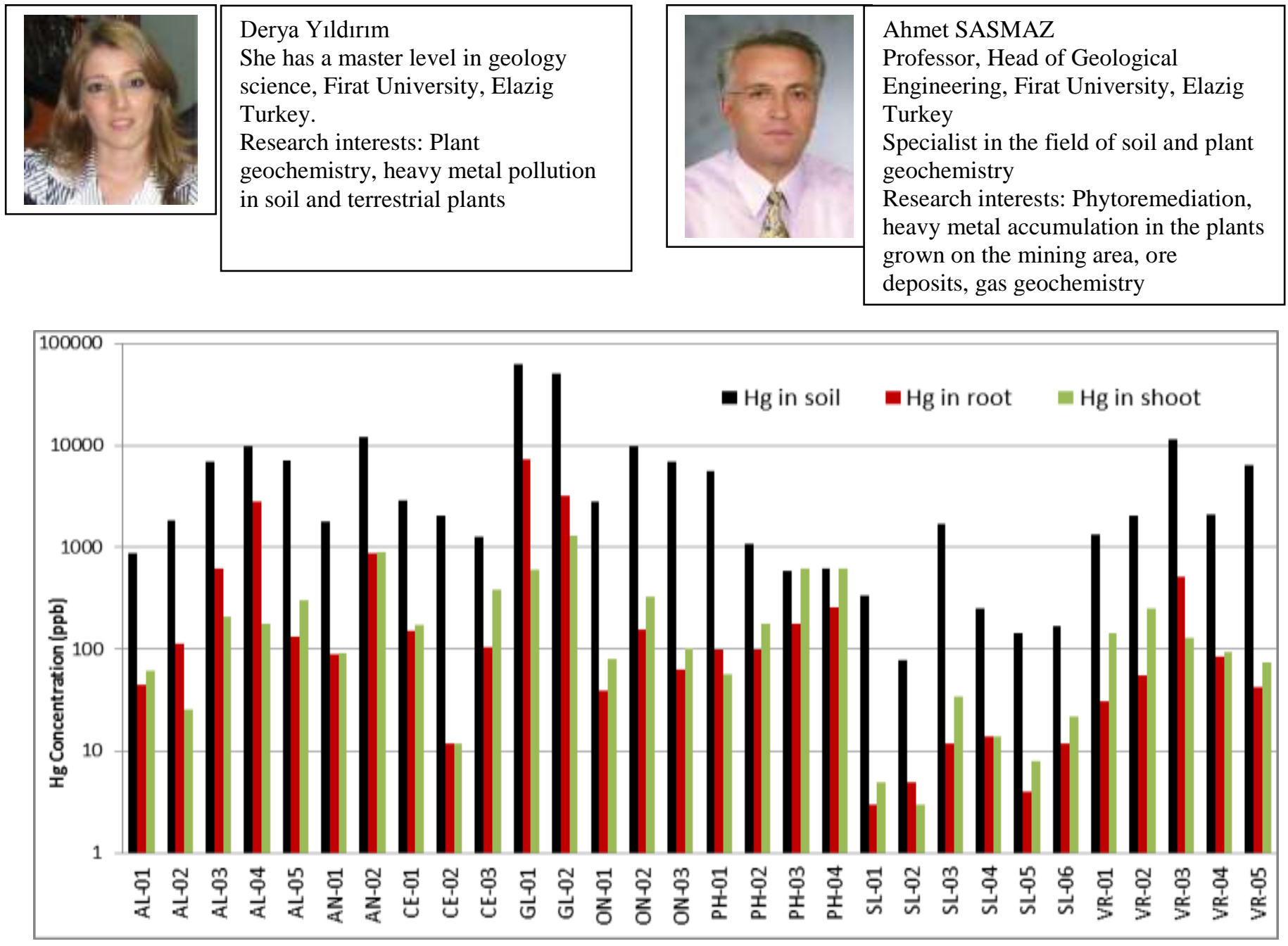

Figure 1: The $\mathrm{Hg}$ concentrations of soils, roots and shoots of 12 plant species.

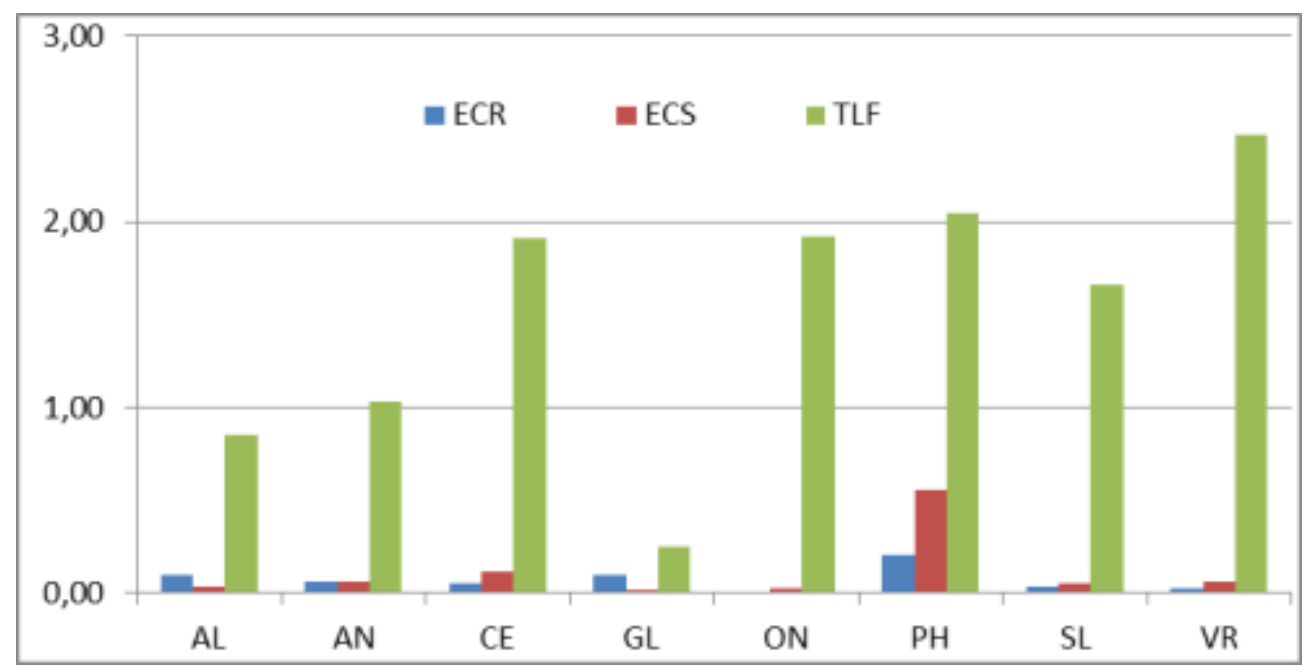

Figure 2. Mean translocation factors (TLF) and enrichment coefficients for roots (ECR) and shoots (ECS) of plants in the study area. 